\title{
KINERJA BAGIAN HUKUM DAN ORGANISASI SEKRETARIAT DAERAH KOTA BAUBAU DALAM ERA OTONOMI
}

\author{
Anwar Sadat \\ Program Studi Ilmu Pemerintahan, Fakultas Ilmu Sosial dan Ilmu Politik, \\ Universitas Muhammadiyah Buton, Jl. Betoambari No. 36 Baubau. \\ E-mail:nuansa9@gmail.com
}

\begin{abstract}
Abstrak
Tujuan penelitian ini untuk mengetahui kinerja Bagian Hukum dan Organisasi Sekretariat Daerah Kota Baubau dalam era otonomi. Penelitian ini menggunakan Jenis penelitian deskriptif. Penelitian langsung ke Kantor Sekretariat Kota Baubau, tepatnya Bagian Hukum dan Organisasi. Hasil penelitian menunjukan bahwa kinerja Bagian Hukum dan Organisasi Sekretariat Daerah Kota Baubau bila dilihat dari tugas dan fungsi secara aktual yang dilaksanakannya sehari-hari dalam era otonomi sekarang ini masih rendah dan belum optimal, masih banyak hanya sekedar ide belaka dan belum ditindaklanjuti secara nyata. Rendahnya kinerja Bagian Hukum dan Organisasi dipengaruhi oleh faktor profesionalisme dan faktor struktur. Hal tersebut dibuktikan juga dari hasil penelitian aspek pembagian tugas yang belum jelas dan masih terdapat tumpang tindih pekerjaan, begitu pula dari aspek kewenangan yang belum sepenuhnya diserahkan kepada pegawai sesuai dengan kedudukan dan jabatan yang ada. Yang mana semuanya itu mennyebabkan rendahnya faktor struktur yang ada pada Bagian Hukum dan Organisasi Sekretariat Daerah Kota Baubau.
\end{abstract}

Kata kunci: kinerja, bagian hukum dan organisasi, otonomi.

\begin{abstract}
The purpose of this research is to know the performance of Legal and Organization Section of City Secretariat of Baubau City in the era of autonomy. This research uses descriptive research type. Research directly to Baubau City Secretariat Office, precisely the Legal and Organization Section. The result of the research shows that the performance of Legal and Organization Division of City Secretariat of Baubau City when viewed from the actual task and function which is carried out daily in the era of autonomy today is still low and not yet optimal, there are still many ideas and have not been followed up clearly. The low performance of the Legal and Organization Section is influenced by professionalism and structural factors. This is evidenced also from the results of research aspects of the division of tasks that are not yet clear and there is still overlapping work, as well as from the aspect of authority that has not been fully submitted to employees in accordance with existing positions and positions. All of which leads to the lack of structural factors that exist in the Legal and Organizational Section of the Baubau City Regional Secretariat.
\end{abstract}

Keywords: performance, legal and organizational sections, autonomy. 


\section{SANG PENCERAH}

Volume 3, Nomor 1, Februari 2017, ISSN 2460-5697, Hlm. 1-15

Anwar Sadat: Kinerja Bagian Hukum dan Organisasi ...

\section{Pendahuluan}

Undang-Undang Nomor 23

Tahun 2014 lebih menitikberatkan otonomi pada daerah

kabupaten/kota, oleh karena pada

kenyataannya daerah

kabupaten/kotalah yang dalam

pelaksanaan sehari-harinya

berhubungan langsung dengan

masyarakat, sehingga dengan

demikian daerah kabupaten/kota

pulalah secara langsung maupun tidak langsung lebih memahami serta dapat menampung masukanmasukan berupa keluhan maupun kritikan ataupun sumbangan pemikiran berupa saran dari masyarakat. Berbicara masalah otonomi daerah, maka masalah penting yang perlu mendapat perhatian bukan saja diukur dari sisi kemampuan daerah dalam menggali sumber-sumber keuangan sendiri, namun titik berat keberhasilan pelaksanaan otonomi daerah tersebut akan banyak ditentukan oleh kemampuan daerah dalam menata, membina struktur kelembagaan pemerintah daerah beserta perangkatnya selaku unsur pelaksananya.

Seiring dengan lahirnya Undang-Undang Nomor 23 Tahun 2014, melalui Peraturan Pemerintah Nomor 41 Tahun 2007 Tentang Pedoman Organisasi Pemerintah Daerah, maka organisasi daerah mengalami perubahan pula. Selama ini organisasi yang ada pada setiap pemda kabupaten/kota cendrung seragam mengikuti ketentuan dari pusat tanpa ada penyesuaian apakah tepat dan cocok pada daerah yang bersangkutan, dengan kata lain daerah tidak bisa lebih kreatif dalam menentukan yang semestinya dibutuhkan dan mana pula yang tidak dibutuhkan. Otonomi daerah yang sarat dengan isu strategi berupa kelembagaan, sumber daya manusia berupa aparatur pelaksana, jaringan kerja serta lingkungan kondusif yang terus berubah merupakan sebuah tantangan bagi Kota Baubau untuk menanggapi serta mensiasatinya dengan tanggap dan cepat agar tidak ketinggalan dari daerah lainnya dalam memacu gerak pembangunan.

Kota Baubau yang selama ini juga sering mencanangkan struktur yang dikecilkan, namun harus memperbanyak fungsi hanyalah sebagai wacana saja, sedangkan pelaksanaannya selalu saja harus berpedoman dengan ketentuan pusat. Pada masa sekarang ini, yaitu era otonomi Kota Baubau mulai berbenah diri dengan tekad yang bulat untuk mempergunakan kesempatan luas yang ada sekarang dalam pembenahan lembaganya. Adapun urusan tersebut dilaksanakan oleh Bagian Hukum dan Organisasi, Peraturan Daerah Nomor 1 Tahun 2011 tentang Struktur Organisasi Sekretariat Daerah Kota Baubau. Lebih lanjut disebutkan, bahwa Bagian Hukum dan Organisasi Sekretariat Daerah Kota Baubau bertugas melaksanakan penyusunan pedoman dan petunjuk teknis pembinaan kelembagaan, ketatalaksanaan, dan Pengembangan analisis jabatan, mekanisme kerja serta perangkatnya.

Namun semuanya itu berpedoman pada aturan pusat yang selama ini bersifat sentralistik, sehingga dalam pelaksanaan pekerjaan sehari-hari terlihat masih banyak tumpang tindih pekerjaan antara satu bagian dengan bagian lainnya, koordinasi yang tidak terlaksana dengan baik. Bila dilihat pula dari beban kerja yang diemban 


\section{Anwar Sadat: Kinerja Bagian Hukum dan Organisasi ...}

tidak ringan dalam era otonomi dan reformasi yang sedang maraknya kala ini, yaitu tuntutan untuk birokrasi yang ramping dan sesuai dengan kebutuhan organisasi serta aparat yang andal dan bersih dalam pelaksanaan tugasnya melalui pengawasan melekat yang juga merupakan cakupan tugas Bagian Hukum dan Organisasi ditambah pula dengan perlunya aparat birokrasi yang tanggap dan terampil serta intelektual dalam bekerja seharihari. Perlunya birokrasi yang sesuai dengan kebutuhan masyarakat saat ini tidak terlepas dari kebutuhan untuk membenahi oraganisasi yang ada dalam Kota Baubau yang perlu dilakukan sesegera mungkin.

Sejalan dengan pelaksanaan Undang-Undang Nomor 23 Tahun 2014, juga dihubungkan lagi dengan Peraturan Pemerintah Nomor 41 Tahun 2007 tentang Pedoman Organisasi Pemerintah Daerah, maka perubahan ini perlu secara cepat disikapi oleh Pemerintah Kota Baubau, yang tentunya menjadi tugas Bagian Hukum dan Organisasi untuk melaksanakannya dengan baik dan seksama mungkin seiring dengan perubahan lingkungan tersebut.

Pembentukan Unit Pelayanan Terpadu yang merupakan gagasan dari Bagian Hukum dan Organisasi sebagai realisasi untuk ke arah pelayanan kepada masyarakat dengan baik belum juga diarahkan ke bentuk yang lebih sempurna dari suatu lembaga yang kurang memberikan kontribusi yang berarti kepada masyarakat sebagai pelayanan yang baik pada saat ini. Bila dilihat dari hasil analisis yang diadakan, seharusnya realisasi untuk Penggabungan atau penambahan organisasi yang baru maupun penyatuan dua organisasi menjadi satu untuk lebih efisien masih juga ada yang belum direalisasikan oleh Bagian Hukum dan Organisasi untuk mengantisipasi secara cepat perkembangan dan kebutuhan pelayanan terhadap masyarakat.

Siklus pekerjaan yang ada dalam lingkup Bagian Hukum dan Organisasi masih mengalami kelambanan, para staf dalam menyelesaikan pekerjaan yang seharusnya bisa diselesaikan dalam waktu singkat, namun masih juga mengalami keterlambatan yang dapat menyebabkan keterlambatan dalam berbagai urusan pelayanan terhadap masyarakat tentunya. Dapat dilihat dari mulai dikeluarkanya Peraturan Pemerintah Nomor 41 Tahun 2007 Tentang Pedoman Organisasi Pemerintah Daerah, Bagian Hukum dan Organisasi baru bisa menyelesaikan Perda tentang Susunan Organisasi bagi organisasi yang ada di Pemda Kota Baubau lebih dari enam bulan. Berdasarkan uraian di atas, fokus penelitian ini adalah bagaimana kinerja Bagian Hukum dan Organisasi Sekretariat Daerah Kota Baubau dalam era otonomi?

Tujuan penelitian ini untuk mengetahui kinerja Bagian Hukum dan Organisasi Sekretariat Daerah Kota Baubau dalam era otonomi.

\section{Metode Penelitian}

\section{Jenis Penelitian}

Penelitian ini menggunakan Jenis penelitian deskriptif. Penelitian langsung ke Kantor Sekretariat Kota Baubau, tepatnya Bagian Hukum dan Organisasi guna mendapatkan gambaran yang tepat, jelas dan terinci bagaimana adanya tentang permasalahan yang ada berdasarkan 


\section{Anwar Sadat: Kinerja Bagian Hukum dan Organisasi ...}

fakta yang bersifat aktual pada saat meneliti. Jenis penelitian deskriptif adalah digunakan untuk pengukuran yang cermat terhadap fenomena sosial tertentu (Singarimbun, 2009: 4).

\section{Data dan Sumber Data}

Adapun sumber data yang penulis peroleh dalam penelitian lapangan ini adalah (1) Data Primer, yakni data yang diperoleh langsung dari para responden berupa informan di lapangan, yang meliputi data tentang pelaksanaan pekerjaan tugas dan fungsi Bagian Hukum dan Organisasisehari-hari dengan segala permasalahan yang ada; dan Data Skunder, yakni data yang diperoleh melalui laporan-laporan/bukubuku/catatan-catatan yang berkaitan erat dengan permasalahan yang diteliti, meliputi data kepegawaian, tugas dan fungsi Bagian Hukum dan Organisasi, mekanisme kerja uraian dan tugas Sub-sub Bagian Hukum dan Organisasi.

\section{Populasi dan Sampel}

Populasi untuk penelitian ini adalah data yang digali peneliti sesuai dengan pokok masalah diantaranya kinerja Bagian Hukum dan Organisasi Sekretariat Daerah dan faktor yang memengaruhinya dan beberapa dokumen-dokumen lain. Adapun populasi dalam penelitian ini berjumlah 22 orang.

Informan dipilih secara purposif (purposiv sampling). Pemilihan informan didasarkan objek penelitian yang menguasi masalah, memiliki data, dan bersedia memberikan data. Sampel penelitian ini sebanyak 11 orang yang terdiri dari 4 orang Kasubag yaitu Kasubag Perundangundangan, dan Dokumentasi Hukum, Kasubag Bantuan Hukum, Kasubag
Kepegawaian, Kasubag Tatalaksana. Dan tujuh orang staf Bagian Hukum dan Organisasi.

\section{Teknik Pengumpulan Data}

Untuk memperoleh data yang dibutuhkan sesuai dengan permasalahan yang diteliti, maka penulis menggunakan teknik pengumpulan data sebagai berikut (1) Teknik dokumentasi, yaitu mengumpulkan data skunder dari berbagai dokumen tertulis, seperti ketentuan peraturan perundangudangan sebagai bahan referensi dan komperasi, selain itu dipergunakan pula sejumlah dokumentasi lainnya yang berasal dari makalah seminar serta sumber data lain, baik yang telah dipublikasikan maupun belum; dan (2) Wawancara langsung secara mendalam (indepth interview), yakni suatu dialog/tanya jawab yang penulis lakukan terhadap nara sumber sebagai informan secara mendalam untuk memperoleh data primer yang objektif dan faktual tentang permasalahan yang diteliti.

\section{Teknik Analisis data}

Semua data yang telah diperoleh dalam penelitian lalu dikumpulkan, selanjutnya dikelompokkan untuk dijadikan sebagai bahan masukan yang akan digunakan sebagai bahan bukti dalam pelaksanaan penulisan ini. Selanjutnya Penulis akan melakukan konfirmasi terhadap informan lainnya untuk bisa memperoleh data yang valid. Setelah data tersebut diolah selanjutnmya Penulis melakukan pembahasan terhadap data yang bersifat kualitatif dalam bentuk deskriptif dengan menganalisanya secara seksama lalu menarik kesimpulan dan pada akhirnya 


\section{SANG PENCERAH}

Volume 3, Nomor 1, Februari 2017, ISSN 2460-5697, Hlm. 1-15

Anwar Sadat: Kinerja Bagian Hukum dan Organisasi ...

memberikan saran-saran yang dapat diberikan kepada Bagian Hukum dan Organisasi Sekretariat Kota Baubau dalam rangka peningkatan kinerjanya dalam era otonomi sekarang ini.

\section{Pembahasan}

\section{Kinerja Bagian Hukum dan Organisasi Sekretariat Kota Baubau dalam Melaksanakan Tugas dan Fungsinya Secara Aktual}

Peraturan Daerah Kota Baubau Nomor 1 Tahun 2011 Tentang Perubahan Peraturan Daerah Daerah Kota Baubau Nomor 1 Tahun 2008 Tentang Organisasi dan Tata Kerja Sekretariat Daerah, Sekretariat Dewan Perwakilan Rakyat Daerah, dan Staf Ahli Walikota Baubau, menyatakan bahwa.

"Bagian Hukum dan Organisasi
mempunyai tugas membina dan
melaksanakan sebagian tugas
Sekretariat Daerah dalam
menyiapkan kebijakan penataan
organisasi ketatalaksanaan dan
analisis jabatan di lingkungan
Pemerintah Kota Baubau serta
merumuskan kebijakan fasilitasi
pelaksanaan penataan organisasi
Pemerintah Kota berdasarkan
peraturan perundang-undangan
yangberlaku".

Berikut dikemukakan tugas dan fungsi yang telah dilaksanakan oleh Bagian Hukum dan Organisasi.

\section{Menyusun Bahan Pedoman dan Petunjuk Teknis Kelembagaan dan Ketatalaksanaan}

Dalam melaksanakan tugas dan fungsinya ini Bagian Hukum dan Organisasi telah memikirkan dan melakukannya sesuai dengan bidangnya, terutama dalam mewujudkan suatu lembaga yang handal sesuai dengan tuntutan dalam era otonomi. Bagian Hukum dan Organisasi telah menyusun suatu rencana untuk merevisi lembaga-lembaga yang sudah tidak sesuai lagi dengan era reformasi.

Untuk itu Bagian Hukum dan Organisasi telah memikirkan akan membuat petunjuk teknis bagi pembentukan nama lembaga instansi yang sesuai dengan tugas dan fungsinya. Hal tersebut sesuai dengan yang dikemukakan oleh Mohamad Tasdi Kabag Hukum dan Organisasi dalam wawancara berikut ini:

"Dalam melaksanakan tugas dan fungsi sehari-hari kami telah melakukan semaksimal mungkin dengan berbagai terobosan yang berusaha menjawab tantangan dalam era otonomi yang sedang bergulir kala ini" (Wawancara tanggal 12 November 2016).

\begin{tabular}{llr}
\multicolumn{1}{c}{ Bagian } & Hukum & $\begin{array}{r}\text { dan } \\
\text { Okan }\end{array}$ \\
merekomisasi & tidak & untuk
\end{tabular}
pembuatan suatu lembaga bila tidak mendukung ke arah otonom dalam membuat suatu kebijakan dan birokrasi serta prosedur administrasi, dengan demikian lebih mengutamakan sisi efisiensi. Hal ini menunjukkan bahwa Bagian Hukum dan Organisasi belum dapat melaksanakan tugas di bidang penyusunan bahan dan pedoman dan petunjuk teknis kelembagaan secara keseluruhan. Masih ada hanya sebatas ide yang belum direalisasi sesuai dengan yang diharapkan. 


\section{SANG PENCERAH}

Volume 3, Nomor 1, Februari 2017, ISSN 2460-5697, Hlm. 1-15

Anwar Sadat: Kinerja Bagian Hukum dan Organisasi ...

2. Fasilitasi Pelaksanaan Penataan

Kelembagaan dan Ketatalaksanaan

Berdasarkan peraturan

perundang-undangan Bagian

Hukum dan Organisasi telah merumuskan dan melaksanakan serta menyiapkan bahan penyusunan pedoman dan petunjuk teknis pembinaan kelembagaan daerah Kota Baubau, selanjutnya dirumuskan dan dipersiapkan menjadi rancangan peraturan daerah tentang penyempurnaan, pengembangan, pembentukan dan penghapusan satuan organisasi Daerah Kota Baubau.

Dari hasil kerjanya tersebut telah disahkan Peraturan Daerah Nomor 1 Tahun 2011 tentang Pembentukan Susunan Organisasi dan Tata Kerja Sekretariat Daerah, Sekretariat DPRD dan Pemerintah Kecamatan dan Kelurahan dalam Kota Baubau, Dari Perda tersebut diketahui dalam tubuh Sekretariat Daerah Kota Baubau terdapat 9 sembilan bagian, di bawahi oleh tiga asisten, yaitu Asisten Pemerintahan dan Kesejahteraan Rakyat, Asisten Perekonomian, dan Asisten Administrasi Umum. Namun masih ada tumpang tindih pekerjaan antara suatu bagian dengan dinas. Seperti adanya Bagian Administrasi Pengelolaan SDA pada Sekretariat Daerah Kota Baubau, juga ada Dinas Pertambangan dan Lingkungan Hidup, hal ini tentunya akan membuat masyarakat bingung bila ingin mendapatkan pelayanan. Berikut tanggapan Mohamad Tasdik sebagai Kepala Bagian Hukum dan Organisasi.
"Kami telah memikirkan akan melakukan penyatuan Dinas Pertambangan dan Dinas Lingkungan Hidup dengan Bagian Administrasi Pengelolaan SDA dengan pertimbangan agar tidak terjadi over laping atau tumpang tindih dalam pelaksanaan tugas sehari-hari" (Wawancara tanggal 12 November 2016).

Dari keadaan tersebut dapat dikatakan bahwa pelaksanaan tugas Bagian Hukum dan Organisasi Sekretariat Daerah Kota Baubau memfasilitasi penataan pelaksanaan kelembagaan belum terlaksana secara keseluruhan dengan baik. Dalam melaksanakan tugas ini Bagian Organisasi merumuskan dan melaksanakan serta mempelajari peraturan perundang-undangan, kebijaksanaan teknis, pedoman dan petunjuk teknis serta bahan-bahan lainnya di bidang ketatalaksanaan. Semuanya itu harus dirumuskan dan dihimpun dalam bentuk pedoman kerja dan prosedur kerja, sistem kerja dan metode kerja. Dengan demikian dapat diketahui bahwa pelaksanaan tugas Bagian Hukum dan Organisasi Sekretariat Daerah Kota Baubau dalam menyusun bahan pedoman dan petunjuk teknis pelaksanaan kelembagaan dan ketatalaksanaan belum terpenuhi secara baik.

3. Penyusunan Kebijakan Fasilitasi Pelaksanaan Penataan Organisasi Pemerintah Kota

Bagian Hukum dan Organisasi dalam melaksanakan tugas dan fungsinya sehari-hari tidak hanya menata oragnsiasi di lingkungan Sekretariat Daerah 


\section{SANG PENCERAH}

Volume 3, Nomor 1, Februari 2017, ISSN 2460-5697, Hlm. 1-15

\section{Anwar Sadat: Kinerja Bagian Hukum dan Organisasi ...}

Kota Baubau saja, namun lebih jauh meliputi pelaksanaan penataan oragnisasi Pemerintah Kota Baubau. Dalam rangka mewujudkan good governance supaya dapat melayani masyarakat dengan baik, Bagian Hukum dan Organisasi memberi gagasan pendirian Unit Pelayanan Umum Terpadu melayani masyarakat mengurus berbagai izin lebih mudah prosedurnya agar tidak terjadi birokrasi yang berbelit-belit.

Bila masalah tenaga terampil dan ahli menjadi kendala, Bagian Hukum dan Organisasi seharusnya mencari jalan keluar yang bisa memberikan jawaban terhadap perlunya untuk pengisian jabatan fungsional secara cepat agar tuntutan reformasi yang menghendaki struktur dikecilkan, kaya fungsi dapat dipenuhi Bagian Hukum dan Organisasi dalam menjalankan tugas dan fungsinya. Setelah mengetahui keadaan tersebut dapat dikatakan bahwa pelaksanaan tugas dan fungsi Bagian Hukum dan Organisasi dalam menyusun kebijakan fasilitasi pelaksanaan penataan organisasi pemerintah Kota Baubau belum dilakukan secara keseluruhan.

\section{Pelaksanaan Administrasi dan Tata Usaha}

Dalam pelaksanaan administrasi dan tata usaha pada Bagian Hukum dan Organisasi diusahakan dilakukan berdasarkan uraian tugas yang ada. Setiap surat yang masuk harus terlebih dahulu diregistrasi selanjutnya diajukan melalui disposisi kepada Kabag. Setelah ditelaah Kabag lalu didistribusikan sesuai bidangnya menurut kasubbag yang ada.
Kasubbag perlu menindaklanjuti surat tersebut berupa draft surat yang selanjutnya diajukan kepada Kabag. Bila draft tersebut sesuai dengan tujuan dan maksudnya dan memenuhi syarat, maka Kabag memaraf untuk diteruskan ke atas yang diantar dengan telaahan staf mohon tanda tangan kepada Asisten, Sekda atau Walikota agar surat tersebut bisa diproses lebih lanjut.

Namun proses administrasi tersebut belum tentu selalu berjalan mulus, hal ini tentunya disebabkan oleh berbagai masalah seperti kurang responnya Kasubbag terhadap tugasnya, sehingga surat yang masuk tidak ditanggapi secara cepat ataupun sudah ditanggapi namun lamban dan kurang kreatif, seperti kurang mengerti dengan permasalahn yang ada. Menanggapi keadaan tersebut Kabag memberikan pekerjaan tersebut kepada Kasubbag lain, kadang juga langsung kepada staf yang lebih mengerti dengan masalah yang ada. Hal tersebut dilakukan agar pekerjaan berjalan lancar dan efisien. Hal ini pula yang sering menghambat lancarnya pelaksanaan tugas.

\section{Interpretasi}

Sebagaimana yang telah penulis uraikan di atas bahwa Bagian Organisasi dalam menjalankan tugas dan fungsinya sehari-hari secara aktual, yang mana tugas dan fungsinya tersebut sangat berperanan dalam pembinaan organisasi dan tatalaksana dengan membina dan meningkatkan kapasitas kelembagaan dan ketatalaksanaan seluruh unit kerja sekretariat Kota 


\section{SANG PENCERAH}

Volume 3, Nomor 1, Februari 2017, ISSN 2460-5697, Hlm. 1-15

Anwar Sadat: Kinerja Bagian Hukum dan Organisasi ...

Baubau khususnya dan Pemerintah Kota pada umumnya. Melihat keadaan tersebut Bagian Hukum dan Organisasi dituntut untuk menghasilkan kinerja yang baik sebagai tolok ukur keberhasilannya dalam pelaksanaan tugas sehari-hari. Dalam menyusun bahan pedoman dan petunjuk teknis kelembagaan belum dilaksanakan secara keseluruhan, yaitu ide tentang revisi Dinas Kota Baubau belum juga dituangkan dalam draft yang nyata.

Di dalam melaksanakan fasilitasi pelaksanaan penataan kelembagaan, Bagian Hukum dan Organisasi belum melaksanakan secara keseluruhan, hal tersebut dapat dilihat adanya tumpang tindih pelaksanaan tugas yang dilakukan oleh Bagian Administrasi Pengelolaan SDA Sekretariat Daerah Kota Baubau dengan Dinas Pertambangan dan Dinas Lingkungan Hidup, Bagian Hukum dan Organisasi belum melaksnakannya sesuai dengan SOT baru, oleh karena itu belum ada secara manual informasi yang lengkap tentang informasi jabatan. Dengan demikian pegawai yang telah diikutkan dalam penataran pengawasan Melekat tidak diberdayakan.

Dalam penyusunan kebijakan fasilitasi pelaksanaan penataan organisasi Pemerintah Kota Baubau, Bagian Hukum dan Organisasi belum juga melaksanakannya secara keseluruhan, dapat dilihat dari ide pembentukan Unit Pelayanan Umum Terpadu yang merupakan gagasan Bagian Hukum dan Organisasi hingga saat ini belum juga diupayakan menjadi suatu organisasi yang berkewenangan penuh, karena masih berupa SK Walikota. Pengisian jabatan fungsional di lingkungan pemda Kota Baubau belum dipersiapkan secara baik, sedangkan waktunya udah mendesak.

\section{Faktor-faktor Memengaruhi Kinerja Bagian Hukum dan Organisasi Sekretariat Kota Baubau}

Setelah dilihat kinerja Bagian Hukum dan Organisasi secara aktual sehari-hari yang pada kenyataannya rendah. Begitu pula bila dilihat dari kinerjanya dalam mencapai visi dan misi Kota Baubau juga masih rendah. Selanjutnya dapat pula kita lihat faktor-faktor yang menyebabkannya.

\section{a. Profesionalisme}

Tenaga pegawai $\begin{array}{r}\text { yang } \\ \text { dalam }\end{array}$
profesional
penyelenggaraan tugas dan fungsi
Bagian Hukum dan Organisasi
Sekretariat Kota
dibutuhkan angh
penyelenggaraan pemerintahan
yang baik sesuai dengan tuntutan
pelayanan yang prima kepada
masyarakat. Profesional bagi
Bagian Hukum dan Organisasi
adalah merupakan kemampuan
pegawai untuk bisa bekerja dengan
baik dibutuhkan kesungguhan
dalam bekerja agar mampu
melaksanakannya dengan baik dan
bertanggungjawab.

a. Kesungguhan Bekerja Pegawai Dalam melaksanakan tugas dan fungsi sehari-hari dibutuhkan kesungguhan dalam melakukan pekerjaan agar hasil pekerjaan sesuai dengan harapan yang menjadi tujuan organisasi. Sesuai dengan pengamatan penulis 


\section{SANG PENCERAH}

Volume 3, Nomor 1, Februari 2017, ISSN 2460-5697, Hlm. 1-15

Anwar Sadat: Kinerja Bagian Hukum dan Organisasi ...

pada Pegawai Bagian Hukum

dan Organisasi dalam melaksanakan pekerjaan seharihari masih terlihat adanya kesan kurang sungguh-sungguh dalam menghadapi pekerjaan. Hal tersebut nampak dari keterlambatan pegawai masuk kantor, hal tersebut bukan saja menyangkut masalah apel pagi atau siang, namun lebih kelihatan pada saat jam kerja yang mana seharusnya para pegawai melaksanakan pekerjaannya dengan serius dan bersungguh-sunguh, akan tetapi lebih banyak menonton televisi. Bila memasuki ruangan hanya sebentar saja. Ada yang bekerja hanya bertahan satu jam saja.

Keadaan tersebut dapat dilihat dari pekerjaan yang dihasilkannya selalu tidak sesuai dengan yang diharapkan kabag. Bila ada disposisi surat dari atas (Asisten III, Sekda atau Walikota), setelah dicermati Kabag lalu disalurkan pada Kasubbag yang berhubungan dengan bidang kerjanya, namun surat tersebut baru ditanggapi oleh kasubbag setelah beberapa hari, itupun bila kabag menanyakannnya kembali. Keadaan tersebut dapat dilihat dari hasil wawancara dengan Pegawai Bagian Hukum dan Organisasi sebagai berikut.

"Jam masuk dan pulang pegawai di sini tidak harus sesuai dengan aturan yang ada, pelaksanaan pekerjaan juga tidak harus saya kerjakan, oleh karena bisa dikerjakan orang lain" (Tanggal, 13 November 2016).

Keadaan di atas
menunjukkan
pegawai Bagian
$\begin{aligned} & \text { Hukumguhan dan } \\ & \text { Organisasi }\end{aligned}$
pekerjaannya masih rendah.

\section{b. Kemampuan Bekerja Pegawai}

Berdasarkan pengamatan dan data yang penulis peroleh, dalam melaksanakan tugas dan fungsi sehari-hari pegawai Bagian Hukum dan Organisasi selalu diarahkan dari Kabag sebagai atasan. Pekerjaan yang dilakukan pegawai lebih banyak dilakukan berdasarkan ide Kabag. Dengan demikian inisiatif lebih kreatif dalam bekerja sangat rendah pada diri pegawai Bagian Hukum dan Organisasi. Dari Kemampuan dan mengonsep berbagai surat lebih banyak dilakukan kabag. Hanya sebagian kecil pegawai yang mampu menafsirkan apa yang dikehendaki Kabag dalam menanggapi surat-surat yang hendak diolah. Menurut kabag Bagian Organisai dari hasil wawancara sebagai berikut.

"Dari tiga orang Kasubbag yang ada, hanya seorang saja yang bisa diandalkan untuk dipercayakan melaksanakan pekerjaan tanpa harus ragu dengan kemampuan yang dimilikinya. Sedangkan dari tujuh staf yang ada, hanya seorang saja yang mampu melakukan pekerjaan sesuai dengan yang diharapkan Kabag Bagian Hukum dan Organisasi" (Tanggal 13 November 2016). 


\section{SANG PENCERAH}

Volume 3, Nomor 1, Februari 2017, ISSN 2460-5697, Hlm. 1-15

Anwar Sadat: Kinerja Bagian Hukum dan Organisasi ...

\section{c. Tanggung Jawab dalam Melaksanakan Tugas}

Dalam melaksanakan tugas dan fungsi sehari-hari pegawai Bagian Hukum dan Organisasi tidak terlepas dari tanggungjawab atas pekerjaan yang dilakukannya. Tanggung jawab yang ada dilakukan pada pihak yang memberikan wewenang, yaitu pihak atasan sesuai dengan jenjang organisasi. Timbulnya tanggungjawab akibat dari adanya pemberian wewenang dari atasan kepada bawahan. Berdasarkan Perda Nomor 1 Tahun 2011 Bagian Hukum dan Organisasi terdiri dari Sub Bagian Perundang-undangan dan Dokumentasi Hukum, Sub Bagian Bantuan Hukun dan HAM, Sub Bagian Kelembagaan dan ketatalaksanaan, dan Sub Bagian Kepegawaian. Keempat Sub Bagian tersebut telah diberikan uraian tugasnya sesuai dengan Keputusan walikota Baubau Nomor 139 Tahun 2011.

Dengan adanya uraian tugas tersebut kewenangan telah diberikan secara legalitas. Dalam pelaksanaan tugas sehari-hari Kepala Bagian memberikan tugas untuk dilaksanakan kepada masing-masing kasubbag. Tugas yang diberikan kepada kasubbag tidak semuanya dapat dilakukan dengan penuh rasa tanggung jawab. Acapkali tugas yang diberikan dibiarkan begitu saja, sehingga masalah yang perlu mendapat tindakan secepatnya menjadi lamban. Hal ini terjadi disebabkan kurangnya rasa tanggung jawab kasubbag dan kabag terhadap pekerjaan yang ada. Di sisi lain ada kasubbag yang tidak mengerti dengan tugas yang harus dilaksanakan, namun tidak mau bertanya, mempelajari maupun melakukannya dengan seksama, sehingga tugasnya dilakukan oleh Kasubbag lain. Dapat diilihat dari hasil wawancara dengan Mohamad Tasdik selaku Kabag. Hukum dan Organisasi, berikut ini.

"Pekerjaan telah diberikan kepada masing-masing Kasubbag, namun ada dua Kasubbag saja yang respon dan bertanggung jawab terhadap pekerjaan yang diberikan" (Wawancara tanggal 15 November 2016).

Dua orang Kasubbag yang tidak respon terhadap tugas yang yang diberikan kepadanya menunjukkan kurangnya rasa tanggung jawab terhadap tugas dan fungsi dalam bidang tugasnya. Selanjutnya ada porsi tugas yang harus dilaksanakan oleh staf menurut pembagian tugas yang diberikan oleh kabag. Dari tujuh orang pegawai di Bagian Hukum dan Organisasi, empat di antaranya staf. Satu orang dari staf tersebut bertugas sebagai operator komputer. Satu orang sebagai distributor surat, dua orang lagi bertugas sebagai staf administrasi dan registrasi surat. Para staf bekerja berdasarkan perintah dari para Kasubbag.

Hasil pekerjaan para staf disampaikan terlebih dahulu kepada Kasubbag. Apabila telah diperiksa dan disetujui dengan paraf Kasubbag, surat yang diolah sudah layak untuk dikirimkan. Bila ada kesalahan dalam isi, format dan prosedur pekerjaan Kasubbag lebih banyak menyalahkan staf, dengan demikian Kasubbag mengelak dari rasa tanggung jawab. Setelah dicermati tanggung jawab Pegawai Bagian Hukum dan Organisasi dalam melaksankan tugas dan fungsinya masih rendah. 


\section{SANG PENCERAH}

Volume 3, Nomor 1, Februari 2017, ISSN 2460-5697, Hlm. 1-15

Anwar Sadat: Kinerja Bagian Hukum dan Organisasi ...

\section{d. Interpretasi}

Dari analisis terhadap kesungguhan bekerja Pegawai Bagian Hukum dan Organisasi Sekretariat Daerah Kota Baubau masih rendah hal ini dapat dilihat dari kurang disiplinnya para pegawai dalam pelaksanaan tugas, sedangkan kemampuan bekerjanya juga rendah, karena kemampuan pegawainya tidak didukung oleh pendidikan, kursus dan latihan dalam bidang tugasnya sehari-hari. Hal tersebut juga terlihat dari rendahnya rasa tanggung jawab pegawai dalam melaksanakan tugasnya. Dengan demikian dapat diinterpretasikan bahwa faktor profesionalisme pegawai Bagian Hukum dan Organisasi masih rendah.

\section{Struktur}

Struktur merupakan hal yang tidak terlepas dalam setiap organisasi oleh karena struktur akan dapat menggambarkan bagaimana suatu organisasi bergerak melalui tangantangan individu yang ada di dalamnya. Adapun Struktur Organisasi yang baik tentunya struktur yang bisa menjawab tantangan pada era otonomi kini dan berorientasi kepada kepentingan masyarakat banyak yang perlu dilayani sesuai visi dan misi organisasi yang diharapkan akan dapat meningkatkan kinerja organisasi serta profesionalisme bagi para individu yang bekerja di dalamnya.

Setelah penulis cermati di lapangan serta data-data yang diperoleh dapatlah disimpulkan, bahwa yang menonjol dan krusial dalam Struktur yang relevan untuk dijadikan indikator dalam faktor memengaruhi kinerja Bagian Hukum dan Organisasi Sekretariat Kota Baubau, yakni Kejelasan pembagian tugas; Kejelasan penyerahan dan pendelegasian kewenangan; Tingkat Koordinasi antar sub bagian, dengan Bagian Kepegawaian, serta koordinasi dengan pejabat atasannya, yaitu Pemerintah Kota sebagai dukungan dalam pelaksanaan tugas Bagian Hukum dan Organisasi. Berdasarkan hasil penelitian penulis dapat dipaparkan analisa tentang struktur organisasi pada Bagian Hukum dan Organisasi Sekreatriat Kota Baubau sebagai berikut.

\section{a. Kejelasan Pembagian Tugas}

Hal ini benar-benar harus diperhatikan agar pekerjaan yang ada terbagi dengan jelas sesuai dengan bidangnya masing-masing guna menghindari terjadinya tumpang tindih pekerjaan. Berdasarkan data dan pengamatan penulis di lapangan. Pekerjaan lebih banyak dilakukan oleh kasubbag, dengan demikian yang bekerja dan selalu kelihatan sibuk hanyalah kasubbag sedangkan staf lebih banyak duduk termenung sambil menonton televisi, hanya ada segelintir staf yang sibuk melakukan pekerjaan. Hal tersebut terjadi, oleh karena staf tidak mengerti dengan uraian tugas yang telah diberikan kepadanya, pada sisi lain uraian tugas yang diberikan juga terlalu luas dan mengambang, sehingga para staf bingung harus mengerjakan yang mana.

Sedangkan tugas yang diberikan kepada seorang kasubbag acapkali bukan merupakan bidang tugasnya, dengan kata lain tidak sesuai tugas pokok dan fungsinya serta uraian tugas yang telah diberikan, sehingga beban tugas terkesan lebih banyak pada suatu kasubbag saja, sedangkan kasubbag lainnya sepi tanpa kerja. Dengan demikian terjadilah tumpang tindih pekerjaan. Ada pula staf yang mengerjakan pekerjaan yang seharusnya dilakukan oleh kasubbagnya, namun oleh karena kasubbag kurang mengerti dan tidak 


\section{SANG PENCERAH}

Volume 3, Nomor 1, Februari 2017, ISSN 2460-5697, Hlm. 1-15

Anwar Sadat: Kinerja Bagian Hukum dan Organisasi ...

kreatif, maka pekerjaan tersebut diserahkan kabag kepada staf. Keadaan tersebut bila dilihat sepintas baik, karena bisa menyelesaikan pekerjaan relatif singkat, namun bila dibiarkan berlarut-larut tentunya akan menimbulkan masalah dalam organisasi, yaitu timbulnya rasa tidak adil antara individu yang ada. Dengan demikian hal tersebut akan menimbulkan pertentangan. Untuk mengetahui lebih lanjut tentang ini dapat ditelusuri hasil wawancara dengan Pegawai Bagian Hukum dan Organisasi. Berikut Wawancara dengan L.M. Harmasi sebagai Kepala Subbag Kepegawaian sebagai berikut.

"Uraian tugas telah saya baca dengan baik, namun masih banyak yang belum jelas dan mengambang. Pekerjaan yang diberikan kabag sering pula kurang jelas sehingga pekerjaan yang dilakukan cendrung salah sehingga harus diperbaiki berulang kali dengan demikian menjadi lamban. Pekerjaan yang ada belum didistribusikan dengan baik, kadang saya harus mengerjakan pekerjaan subbag lain" (Tanggal 15 November 2016).

Ketika ditanyakan
Kasubbag Kelembagaan
Ketatalaksanaan Erawati,
dan
berkomentar sebagai berikut:
"Memang kadang-kadang saya
dapati tugas saya dikerjakan oleh
subbag lain, menurut saya ini wajar,
namun kalau selalu demikian
membuat saya kehilangan
pekerjaan" (Wawancara tanggal
15 November 2016).

Selanjutnya hasil wawancara dengan Arief Budianto Gavoer sebagai Kasubbag Bantuan Hukum dan HAM, sebagai berikut:
"Pekerjaan yang ada dapat saya laksanakan, sebab udah merupakan rutinitas bagi saya. Memang selalu ada pekerjaan subbag lain saya lakukan, bagi saya ini merupakan saling membantu saja, saya tidak keberatan bila tidak sering, namun kalau terus-terusan tentunya akan mengganggu tugas pokok saya" (Wawancara tanggal 15 November 2016).

Berikut ini wawancara penulis dengan staf Bagian Hukum dan Organisasi sebagai berikut:

"Pekerjaan yang diberikan kepada saya sering bukan merupakan tugas saya selaku staf pada kasubbag ini, dengan kata lain melakukan tugas orang lain, yah! melencenglah. Pendistribusian pekerjaan kurang merata, siapa yang mau bekerja saja diberi beban yang berat, teman yang lain seolah masa bodoh dengan keadaan ini" (Wawancara tanggal 15 November 2016).

Kemudian, menanggapi semua wawancara di atas penulis berusaha untuk mewawancarai Kabag Hukum dan Organisasi sebagai berikut.

"Memang ada kalanya pekerjaan yang saya distribusikan tidak pada bidangnya, hal ini untuk mengantisipasi agar cepat selesai dan sesuai dengan waktu dan hasil yang dikehendaki atasan, karena selalu saja pada saat dibutuhkan tenaganya untuk melakukan pekerjaan yang bersangkutan tidak berada di tempat. Dapat dikatakan pegawai yang ada tidak profesional dalam bekerja" (Wawancara tanggal 15 November 2016).

Dari hasil wawancara Penulis dengan segala unsur pegawai yang ada pada Bagian Hukum dan 


\section{SANG PENCERAH}

Volume 3, Nomor 1, Februari 2017, ISSN 2460-5697, Hlm. 1-15

Anwar Sadat: Kinerja Bagian Hukum dan Organisasi ...

Organisasi di atas dapatlah diketahui bahwa pembagian tugas yang ada belum jelas, walaupun ada dalam uraian tugas, namun belum dimengerti pegawai dengan jelas, sedangkan pekerjaan didistribusikan acapkali tidak pada job yang telah ditentukan dengan peraturan perundangan.

\section{Hubungan Antara Profesionalisme dan Struktur dengan Kinerja Bagian Hukum dan Organisasi Sekretariat Daerah Kota Baubau}

Setelah mencermati dan menganalisis Kinerja Bagian Hukum dan Organisasi Sekekretariat Daerah Kota Baubau dalam melaksanakan tugas dan fungsinya secara aktual sehari-hari dan faktor-faktor yang memengaruhi kinerjanya. Berikut akan dikemukakan hubungan kinerja dengan faktor-faktor yang memengaruhinya, yaitu :

\section{Hubungan antara Faktor Profesionalisme dengan Kinerja}

Profesionalisme merupakan sikap dan prilaku seorang pegawai yang menggambarkan kesungguhan hati dalam bekerja, mampu dan handal, serta bertanggung jawab dalam bidang pekerjaan atau tugas yang dilakukannya untuk melayani masyarakat sesuai dengan bidang kerja yang digelutinya. Pegawai yang profesional akan menghasilkan kerja berkwalitas tinggi sesuai dengan tuntutan masyarakat yang membutuhkan pelayanan.

Pegawai yang andal tentunya bekerja penuh dedikasi serta bersungguhsungguh menekuni pekerjaan yang dilakukannya. Sebagai pelayan terhadap masyarakat Pegawai Bagian Hukum dan Organisasi tidak memilikiki kesungguhandalam melaksanakannya tugas dan fungsinya sehari-hari. Pegawai Bagian Hukum dan Organisasi juga tidak didukung oleh kemampuan bekerja yang baik, oleh karena tidak dibekali oleh pendidikan, latihan serta kursus yang berkaitan dengan tugas dan fungsinya sehari-hari. Selanjutnya dalam melaksankan tugas dan fungsinya Bagian Hukum dan Organisasi tidak memiliki rasa tanggung jawab penuh dalam bidang tugasnya. Dengan demikian Pegawai Bagian Hukum dan Organisasi Sekretariat Daerah Kota Baubau belum bekerja secara profesional, sehingga menyebabkan rendahnya kinerja yang dilakukannya secara aktual sehari-hari dalam era otonomi. Bagian Hukum dan Organisasi Sekretariat Daerah Kota Baubau belum memenuhi kebutuhan pegawai menuju arah profesionalisme, keadaan tersebut memengaruhi kinerja Bagian Hukum dan Organisasi menjadi rendah, sehingga tugas dan fungsi yang dilaksanakan sehari-hari secara aktual belum optimal.

2. Hubungan antara Struktur dengan Kinerja Bagian Hukum dan Organisasi Sekretariat Daerah Kota Baubau

Struktur merupakan faktor penting dalam keberadaan sebuah organisasi, karena struktur secara langsung berkaitan dengan kinerja yang dihasilkan. Struktur pada Bagian Hukum dan Organisasi Sekretariat Daerah Kota Baubau tidak memberikan keleluasaan bagi staf dalam membuat keputusan terhadap bidang kerja yang dilakukan, kewenangan masih berada pada Kabag dalam membuat keputusan Bila ditemui permasaalahan yang harus diputuskan dalam waktu cepat, keadaan ini sulit diatasi, tentunya mengakibatkan kelambanan dalam pelaksanaan tugas dan fungsi sehari-hari.

Dalam melaksanakan tugas dan fungsi sehari-hari pegawai Bagian Hukum dan Organisasi lebih banyak melakukan pekerjaan yang bukan merupakan tugas pokoknya, uraian tugas yang pasti kurang berjalan baik. Keadaan ini membuat pegawai bingung, karena tidak ada kepastian dalam pelaksanaan 


\section{SANG PENCERAH}

Volume 3, Nomor 1, Februari 2017, ISSN 2460-5697, Hlm. 1-15

Anwar Sadat: Kinerja Bagian Hukum dan Organisasi ...

pekerjaan berdasarkan uraian tugas. Hal tersebut memungkinkan hanya seorang pegawai yang mau mengerjakan suatu pekerjaan, akibatnya pekerjaan yang dilakukan lamban. Adanya pekerjaan yang tidak dibagi berdasarkan uraian tugas, hanya dilakukan oleh seorang saja disebabkan pegawai tidak respon terhadap pekerjaan yang sedang dihadapi. Keadaan tersebut menggambarkan koordinasi bawahan dengan atasan kurang berjalan kurang baik. Keadaan struktur yang demikian memengaruhi kinerja Bagian Hukum dan Organisasi Sekretariat Daerah Kota Baubau dalam pelaksanaan tugas dan fungsinya secara aktual sehari-hari, sehingga kinerja yang dihasilkannya rendah, belum dilaksanakan secara optimal.

\section{Interpretasi}

Setelah melakukan analisis hubungan profesionalisme dan struktur dengan kinerja Bagian Hukum dan Organisasi Sekretariat Daerah Kota Baubau, dapat diinterpretasikan bahwa Kinerja Bagian Hukum dan Organisasi Sekretariat Daerah Kota Baubau yang rendah dan belum dilakukan secara optimal dipengaruhi oleh faktor profesionalisme pegawai yang rendah dan struktur yang rendah.

\section{Simpulan}

Simpulan penelitian ini bahwa kinerja Bagian Hukum dan Organisasi Sekretariat Daerah Kota Baubau bila dilihat dari tugas dan fungsi secara aktual yang dilaksanakannya sehari-hari dalam era otonomi sekarang ini masih rendah dan belum optimal, masih banyak hanya sekedar ide belaka dan belum ditindaklanjuti secara nyata. Rendahnya kinerja Bagian Hukum dan Organisasi dipengaruhi oleh faktor profesionalisme dan faktor struktur. Hal tersebut dibuktikan juga dari hasil penelitian aspek pembagian tugas yang belum jelas dan masih terdapat tumpang tindih pekerjaan, begitu pula dari aspek kewenangan yang belum sepenuhnya diserahkan kepada pegawai sesuai dengan kedudukan dan jabatan yang ada. Yang mana semuanya itu mennyebabkan rendahnya faktor struktur yang ada pada Bagian Hukum dan Organisasi Sekretariat Daerah Kota Baubau.

\section{Daftar Pustaka}

Ancok, Djamaludin. 2000. Manajemen Sumber Daya manusia, Hand Out Perkuliahan Manajemen SDM. Yogyakarta: MAP UGM.

Bryant, C \& White, LG. 1982. Managing Development in The third World,West View Press, Mc, diterjemahkan oleh Rustyanto, L .1987. Manajemen Pembangunan untuk Negara Berkembang. Jakarta: LP3ES.

Daha, Khairid. 2002. "Kinerja Organisasi Pelayanan Publik (Studi Kasus pada Kantor Pendaftaran Penduduk Kota Samarinda)", Tesis. Yogyakarta.

Darwin, Muhadjir. 1994.Teori Organisasi Publik, Hand Out Perkuliahan Matrikulasi, Yogyakarta: MAP UGM.

Dwiyanto, Agus. 2001. "Budaya Paternalisme dalam Birokrasi Pelayanan Publik",Policy Brief, Center for Population and Policy Studies, UGM, Yogyakarta.

Etzioni, Amitai. 1982. Organisasi-Organisasi Modern, Terjemahan Suryatim, Jakarta : UI Press. 


\section{SANG PENCERAH}

Volume 3, Nomor 1, Februari 2017, ISSN 2460-5697, Hlm. 1-15

Anwar Sadat: Kinerja Bagian Hukum dan Organisasi ...

Gibson, James. L. 1984. Organisasi dan Manajemen, Perilaku, Struktur, Proses, Jakarta : Erlangga.

Handoko, Hani, T. 1984. Manajemen, Edisi ke II,Yogyakarta : BPFE.

Hasibuan, Malayu S. P. 1994. Manajemen Sumber Daya Manusia,Jakarta : Haji Masagung.

Kartasasmita, Ginandjar. 1997. "Membangun Sumber Daya Sosial Profesional", Bappenas. Jakarta.

Katz, E. F and Lazar Feld, P. F. 1969. Personal Influence, The free press of Glencoe, Illinois, in Second, P.F. E Backman, C. W. 1974. Social Psychologi, Mc.Graw - Hill, Tokyo: Kogakusha.

Keban, Jeremias. T. 1995. "Indikator Kinerja Pemerintah Daerah: Pendekatan Manajemen dan Kebijakan", Makalah, Seminar Sehari, Fisipol UGM, Yogyakarta.

Nasir, Moh. 1988. Methode Penelitian, Jakarta : Ghalia Indonesia.

Numberi, Freddy. 2000. "Organisasi dan Administrasi Pemerintah", Seminar Nasional Profesionalisasi Birokrasi dan Peningkatan Kinerja Pelayanan Publik. Yogyakarta: MAP UGM.

Nystorm and Sturbuck, ed. 1981. Hand Book of Organization Design. Oxford: University Press.

Ratan, H. Waluyo. 1995," Ceramah dan Pengarahan Asisten I Menpan tentang Kelembagaan Pemerintah Kota Jakarta", Jakarta.

Rue and Byars, 1981. Concept Performance, Prentice Hall, New Jersey
Robbins, P. Stephen. 1994. Teori Organisasi, Struktur, Desain dan Aplikasi, Jakarta : Arcan (Terjemahan).

-------. 2001. Perilaku Organisasi, Konsep Kontroversi, Aplikasi, Jakarta : Prenhallindo (terjemahan).

\section{Dokumen}

Bagian Hukum Sekretariat Kota Baubau. 2011, Perda No.01 Tahun 2011, Tentang Struktur Organisasi Sekretariat Daerah Kota Baubau".

Peraturan Pemerintah Nomor 41 Tahun 2007, Tentang Pedoman Organisasi Perangkat Daerah.

Undang-Undang Nomor 23 Tahun 2014, Tentang Pemerintahan Daerah. 